\title{
Impact of Foreign Capital on Economic Growth in Developing Countries: A Debatable Issue in India
}

\author{
Jie Zhang ${ }^{1} \quad$ Yong Lin $^{2 *}$ \\ 1.Jie Zhang, Fujian Academy of Social Sciences, 18 Liuhe Road, Fuzhou, Fujian, China, 350001 \\ 2.Yong Lin, Fujian Academy of Social Sciences, , 18 Liuhe Road, Fuzhou, Fujian, China, 350001
}

\begin{abstract}
Foreign capital is increasingly becoming a significant resource to spur economic growth in many developing countries. This present study used time series data from 1978 to 2014 to investigate the impact of foreign capital on economic growth in India. We found that external debt and foreign remittances lead positively towards economic growth on one hand while on the other hand ODA and FDI negatively affects economic growth in India. The popularly believed argument that foreign capital can help boost economic growth remains an arguable issue in India.
\end{abstract}

Keywords: India, Foreign Capital, Economic Growth

\section{Introduction}

Since independence India maintained its low growth rate for a long time, with an average annual economic growth rate of only 3.5\%. After economic reforms in 1991, economic growth accelerated significantly. During 1993-2002 its average annual growth rate reached about 6\%, and then in 2005 and 2006 over $9 \%$. Due to the financial crisis, the growth rate was slowed down to only $3.89 \%$ in 2008 . The rapid growth recovered in 2009 , with a rate of $8.48 \%$, and then reached $10 \%$. In 2014 and 2015, 7.24\% and 7.57\% respectively. Especially since May 2014, when new Prime Minister Modi took office, GDP growth has surpassed that of China for two consecutive years (7.3\% in 2014 and $7.6 \%$ in 2015), with the aggregate amount of GDP by purchasing power parity ranking the world third.

Foreign capital such as foreign remittances, external debt, foreign development assistance (ODA) and foreign direct investment (FDI) play a critical role in developing economies, but most of the Asian countries imposed a lot of restrictions on foreign capital flows in 1960s and 1970s. This has changed since 1980s, and India has become one of those developing economies which received a massive amount of funds as external debt, official development assistance (ODA), foreign direct investment (FDI) and foreign remittances. After nearly 20 years since the New Economic Policy (NEP) of 1991, India has taken a number of initiatives to attract foreign capital to improve economic growth and became one of the fastest growing economies in the world.

Ever since the economic reform in 1991, India has continuously stepped up its efforts to attract foreign capital. India is the largest recipient of foreign remittances in the world today, and the size of foreign remittances surpassed that of FDI and ODA but fell far behind external debt (see Figure 1). In 1978, the amounts of external debt, foreign remittances, FDI and ODA were respectively 16.25 billion U.S. dollars, 1.16 billion U.S. dollars, 18.09 million U.S. dollars and 1.13 billion U.S. dollars.

Since the late 1970s, both external debt and foreign remittances have enjoyed rapid growth, but ODA remained basically unchanged. During this period, external debt increased faster than the others, ODA increased the slowest, and foreign remittances have already surpassed FDI and ODA in absolute numbers. In 2005-2014, the amount of external debt, foreign remittances, FDI and ODA changed from 121.20 billion U.S. dollars, 22.13 billion U.S. dollars, 7. 22 billion U.S. dollars, and 1.82 billion U.S. dollars to 457.55 billion U.S. dollars , 70.4 billion U.S. dollars , 43.4 billion U.S. dollars and 2.98 billion US dollars respectively. This shows that since the late 1970s, foreign remittances have always been India's second largest source of foreign capital just next to external debt. 


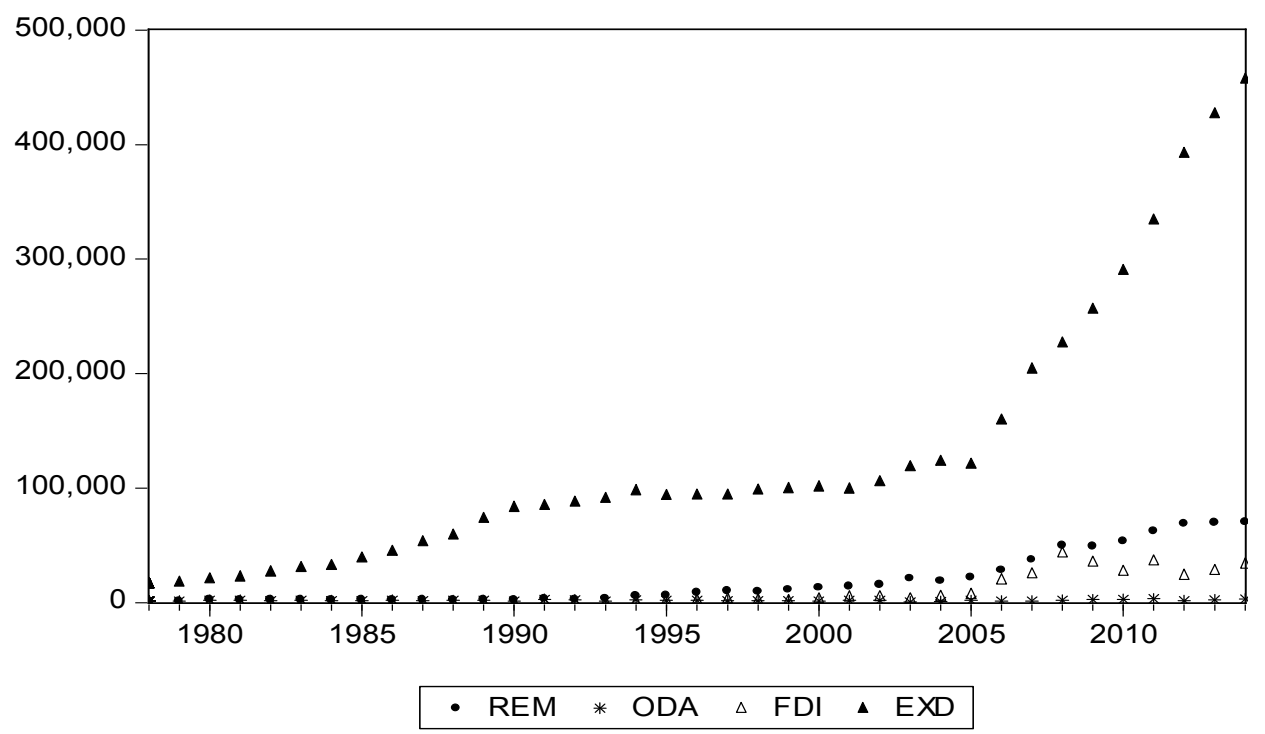

Figure 1. Foreign Remittances, FDI, ODA and External Debt in India (1978-2014),Millions of US dollars Source: World Bank, World Development Indicators,

http://data.worldbank.org.cn/data-catalog/world-development-indicators

The impact of foreign capital on Indian economic growth has been a burning topic of debate in recent years. According to some studies, sufficient foreign capital is necessary for India to obtain high economic growth. Razin (2001) and Edward \& Boskovska (2004) suggested that foreign capital plays an important role in the economic growth of developing countries, and believed that foreign capital has become an indispensable and important resource for developing countries in the economic growth. However, some other studies showed that foreign capital has no significant impact or even negative impact on economic growth(Gorg et al. 2002; Lipsey 2002).

The broad objective of this study is to investigate the relationship between foreign capital and economic growth in India. The specific objectives are:

-To describe the trend of foreign capital in India over the sample period 1978 to 2014.

-To estimate the relationship between foreign capital and economic growth in India.

-To make recommendations based on the estimated results.

The main hypothesis to be tested in this study is stated in null and alternative form as shown below:

H0 : There is no statistically significant positive relationship between ODA and economic growth in India.

$\mathrm{H}_{1}$ : There is a statistically significant positive relationship between FDI and economic growth in India.

$\mathrm{H}_{2}$ : There is a statistically significant positive relationship between remittances and economic growth in India.

$\mathrm{H}_{3}$ : There is a statistically significant negative relationship between external debt and economic growth in India.

In this paper, co-integration analysis and error correction model are used to analyze the impact of foreign remittances, FDI, ODA and external debt on Indian economic growth. The rest of the paper is organized as follows: section two reviews the literature, section three describes the methodology empirical methodology and obtains the results, and section four shows conclusion, discussion and implications.

\section{Literature Review}

Since the first decade of the 21 st century, Indian foreign capital have gradually attracted the attention of scholars, but so far we just have had complex and mixed pictures over the impact of foreign capital on economic growth. A large number of empirical studies have shown that foreign capital had a significant impact on economic growth. Using a multiple regression analysis technique for the period of 1981-2010 in Pakistan, Aurangzeb \& UI Haq (2012) examined the impact of foreign capital inflows on economic growth and the results showed that remittances, external debt and foreign direct investment have a significant positive relationship with economic growth. Interestingly foreign capital is often found to affect economic growth only in the short run (Bussiere et al. 2008; Rangrajan 2000). Additionally many scholars have found that foreign capital has a significant impact on the real exchange rate appreciation, stock market, currency expansion and consumption (Calvo et al. 1994 ; Chakraborty 2003). However, some other studies argued that there was a negative relationship between foreign capital and economic growth (Burnside 1997). Besides, only a few studies did not find any evidence that foreign capital could lead to economic growth in India(Chami et al. 2003; Malik 2009).

Most studies agree that FDI plays a positive role in promoting economic growth (Hanson 2001). In an empirical study Najid et al. (2013) concluded a positive correlation between FDI and growth in Pakistan. Studies by Pradhan (2008) found that there is a bi-directional causality between FDI and growth for India. Using time 
series data from India Sethi \& Patnaik (2007) discovered that FDI positively affects the economic growth. The result of a research program by Blomstrom et al. (1996) \& Borenstein et al. (1998) was that FDI exerted a positive impact on economic growth in countries with a high absorptive capacity, especially the absorptive capacity of its human capital. In 1992, Solow believed that FDI can produce a leveling effect on output per capita by augmenting investment, but not on the growth rate of output.

However, opponents did not agree with them and argued that FDI has a negative impact (Gorg et al. 2002), or has no impact on economy's growth on economic growth of host countries (Lipsey 2002).

Like many other developing countries, India is known for overseas workers and foreign remittances. The empirical evidence of the impact of remittances on economic growth appears to be mixed(Yong Lin 2016). Faini (2002) figured a positive relationship between growth and remittances using cross-country data. Jie Zhang \& Yong Lin(2018) used time series data for China during 1982-2015 and concluded that remittances can accelerate economic growth in China. However, Spatafora (2005) found that there is no direct relationship between real per capita output growth and remittances. Chami et al. (2003), using panel data for 113 developing countries, discovered that remittances have a negative effect on economic growth. While on the other hand, some scholars held that there is no consistent relation between GDP per capita and remittances in Europe and central Asia (Wakayama 2011). Some economists argued that the effects of remittances on economic growth are significant only in the short run but not in the long run (Waheed et al. 2008). In their study for the seven MENA countries in the period of 1975-2006,Mohamed \& Sidiropoulos (2010) used both fixed effect and random effect models to analyze the effect of remittances on economic growth, and their results revealed that remittances have a positive impact on economic growth both directly and indirectly via their interaction with financial and institutional channels.

Economists such as Papanek (1973), Dowling \& Hiemenz (1982), Gupta \& Islam (1983), Hansen \& Tarp (2001) and Burnside \& Dollar( 2000) believed that ODA has a positive effect on economic growth. According to Bacha (1990), ODA is an effective way to supplement government revenue in developing countries. However, some others doubted the positive role of ODA in economic growth and several literatures argued that ODA did not contribute to economic growth in developing countries (Burnside et al. 1997, 2000) . Similarly Mosley (1980) suggested a strong negative association between ODA and economic growth. In Boone's study (1996), in most developing countries ODA is not used mainly for the intended purposes. In summary the literature review shows that the debate of impact of ODA on economic growth has no accurate conclusion yet and ODA effects are different across countries and therefore country specific studies are immediately necessary.

Aurangzeb \& Ul Haq(2012) examined the impact of international capital inflows on growth of Pakistan economy and found that external debt has positive impact on GDP growth. Pattillo et al. (2004) \& Ahmad (2008) considered that external debt promotes industrial development. However, Krugman (1988) \& Hameed et al, (2008) suggested that external debt accumulation has a negative impact on economic growth in developing countries. Malik (2009) used a simple OLS model to investigate the relationship between external debt and economic growth in Pakistan for the period of 1972-2005 and found a significantly negative relation between external debt and economic growth.

Despite the large number of literatures on foreign capital inflows-growth relation, the issue is not clearly resolved. And currently most of the studies are based on cross-country data, whose results should be accepted with careful caution because in such studies a common economic structure and similar production technology are used but these are not accurate in reality (Emeka Nkoro 2012). So it is necessary to verify the impact of foreign capital again in the country level of India.

\section{Empirical Methodology and Results}

\subsection{Methodology}

Papanek (1973) disaggregated foreign capital flows into three main elements as external aid, foreign investment and all other foreign capital, and Oyinlola (1995) disaggregated the foreign capital flows into external debt, foreign direct investment and export earnings. Our study adds another element of foreign remittances and therefore disaggregates foreign capital flows into four main elements: foreign remittances, foreign assistance(ODA), foreign direct investment(FDI), external debt and all other foreign capital. We use time series data from 1978 to 2014 for the variables FDI, external debt, and ODA and foreign remittances. The data have been collected from the World Bank Data Indicators (WDI). Augmented Dicky Fuller (ADF) is used to check whether the variables are stationary or not. Furthermore, we use Johnson co-integration technique to check the long run relationship among all these variables. Moreover, error correction mechanism (ECM) is used to explore the short run relationship between them.

\subsection{Empirical Model Specification}

An appropriate economic model is chosen to investigate the impact of foreign capital on economic growth. All the data for the variables of economic growth (GDP), foreign remittances (REM), official development 
assistance received (ODA), foreign direct investment(FDI), and external debt (EXD) are obtained from World Development Indicators. All computation uses Eviews 8.0.

The following baseline model is:

$$
\mathrm{GDP}=f\left(\mathrm{REM}_{\mathrm{t}}, \mathrm{ODA}_{\mathrm{t}}, \mathrm{FDI}_{\mathrm{t}}, \mathrm{EXD}_{\mathrm{t}}\right) \varepsilon_{\mathrm{it}}
$$

The mathematical specification of the model is: $\mathrm{GDP}=\alpha_{0}+\alpha_{1} \mathrm{REM}+\alpha_{2} \mathrm{ODA}+\alpha_{3} \mathrm{FDI}+\alpha_{4} \mathrm{EXD}+\varepsilon_{\mathrm{it}}$

$\mathrm{GDP}=$ Economic growth as proxy for economic performance is measured by nominal Gross Domestic Product

REM=Foreign Remittances

FDI $=$ Foreign Direct Investment

ODA $=$ Net Official Development Assistance received

$\mathrm{EXD}=$ External Debt

$\mathrm{t}=$ time

$\varepsilon=$ Error term

$\alpha=$ slope coefficient

In a more explicit form, the models can be written in a log-linear form to transform the variables into the same unit and base. Thus:

LNGDP $=\alpha_{0}+\alpha_{1}$ LNREM $+\alpha_{2}$ LNODA $+\alpha_{3}$ LNFDI $+\alpha_{4}$ LNEXD $+\varepsilon_{\text {it }}$

The choice of the log-linear model helps to reduce the gap between the values of the variables such as net official assistance and external debt as to reduce the possibility of the heteroscedasticity in the model.

\subsection{Data}

This study selects the effective data for foreign remittances (REM), foreign direct investment (FDI), official development assistance (ODA), total external debt stock (EXD) and nominal gross domestic product (GDP). All these data are obtained from World Development Indicators (WDI, World Bank). The regression and validation process is done with the econometric software Eviews 8.0.

\subsection{Justification of The Model}

Economic growth can be driven by many factors, but for our analysis four variables are employed, and they are foreign remittances, FDI, ODA and external debt. The foreign remittances and FDI can both play vital roles in the economic growth. The foreign remittances and FDI can cause high investment returns in the domestic economy with impact which can be observed through economic growth. We expect remittances and FDI to have a positive and a significant relationship with economic growth. ODA is the net official development assistance from the government of wealthy countries excluding private contributions or private foreign capital and investments aiming at promoting economic development and welfare of recipient countries. We expect ODA to have a positive and a significant relationship with economic growth. External debt is another macroeconomic tool which is very vital for economic growth if it can be fully utilized accordingly. We also expected external debt to have a positive and a significant relationship with economic growth.

Table 1.Unit root test by Augmented Dickey Fuller (ADF)

\begin{tabular}{|l|l|l|}
\hline \multirow{2}{*}{ Variables } & \multicolumn{2}{|c|}{ ADF } \\
\cline { 2 - 3 } & At Levels & First Differences \\
\hline LN GDP & 0.663745 & -5.552098 \\
\hline LN FDI & -1.166400 & -5.132760 \\
\hline LNODA & -2.664936 & -8.045233 \\
\hline LN REM & -0.258552 & -6.956070 \\
\hline LN EXD & -0.642618 & -3.553498 \\
\hline
\end{tabular}

Using the Augmented Dickey-Fuller we start by testing for stationarity of the individual variables. This test is very important in order to avoid spurious regression. After the series are made stationary (by appropriately differencing them), they can be used in regression analysis. The results of Augmented Dickey Fuller (ADF) test are presented in table 1 . The results of the ADF indicate that the variables of foreign remittances, FDI, ODA and external debt were non-stationary in levels, I [0], but become stationary after first differencing, or integrated of order one, I [1]. The stationary time series of variables were shown in Figure 2. Next, we employ the Johansen Co-Integration test and VEC technique to determine the existence of long-run equilibrium and short-run dynamic changes of the variables. 


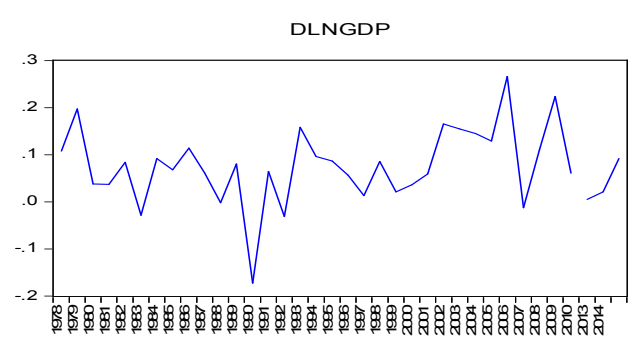

DLNEXD

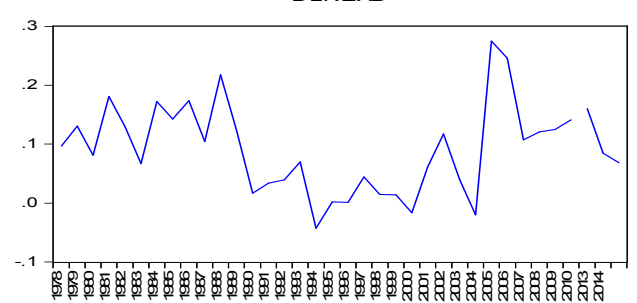

DLNODA

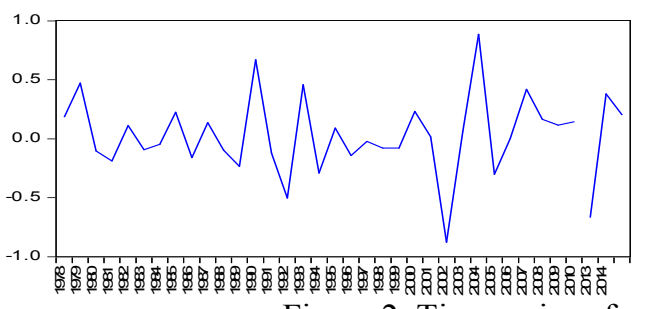

Figure 2. Time series of variables in the first differences

3.5.Lag Length Selection

Before proceeding to ECM , it is important to select appropriate lag length of the variables. Our decision about lag order is based on AIC which is superior and more consistent compared to other criteria. The lag order results are reported in Table 2, and lag length 2 is selected in this study.

Table 2. The lag order results

\begin{tabular}{|c|l|l|l|l|l|}
\hline Lag & LR & FPE & AIC & SC & HQ \\
\hline 0 & NA & $6.60 \mathrm{e}-08$ & -2.343690 & $-2.119225^{*}$ & $-2.267141^{*}$ \\
\hline 1 & 34.66219 & $8.49 \mathrm{e}-08$ & -2.111037 & -0.764248 & -1.651743 \\
\hline 2 & $50.01688^{*}$ & $4.65 \mathrm{e}-08^{*}$ & $-2.815095^{*}$ & -0.345983 & -1.973057 \\
\hline
\end{tabular}

Note: $*$ indicates lag order selected by the criterion.

\subsection{Johansen Co-Integration Test}

As can be seen from the test results in Table 3, there are two co-integration relationships between the five variables under the 5\% significance level, that is, there is a long-term equilibrium relationship between foreign remittances, FDI, ODA, external debt and GDP at a 95\% confidence interval. Co-integration equation is as follows:

$$
\begin{gathered}
\mathrm{LNGDP}=0.418650 \mathrm{LNREM}+0.56431 \text { LLNEXD-0.095565LNFDI-0.006234LNODA (2) } \\
(0.02770) \quad(0.03571) \quad(0.01846) \quad(0.03948)
\end{gathered}
$$

The results show a negative and statistically significant relationship between FDI/ODA and GDP and a significantly positive relationship between foreign remittances/external debt and GDP during the period. The full information on causation can be shown in Error Correction Model (ECM). Hence, we proceed to examine the ECM.

Table 3. Johansen Co-integration Test Results

\begin{tabular}{|l|c|c|c|c|c|}
\hline $\begin{array}{r}\text { Hypothesized No.of } \\
\text { CE(s) }\end{array}$ & Eigen Value & Trace Statistic & $\mathrm{P}$ & Max-Eigen Statistic & \\
\hline $\mathrm{r}=0$ & 0.705532 & 89.53352 & 0.0006 & 41.56793 & 0.0050 \\
\hline $\mathrm{r} \leq 1$ & 0.539397 & 47.96559 & 0.0488 & 26.35745 & 0.0711 \\
\hline $\mathrm{r} \leq 2$ & 0.307769 & 21.60813 & 0.3208 & 12.50643 & 0.4985 \\
\hline $\mathrm{r} \leq 3$ & 0.194945 & 9.101703 & 0.3561 & 7.372723 & 0.4460 \\
\hline $\mathrm{r} \leq 4$ & 0.049581 & 1.728980 & 0.1885 & 1.728980 & 0.1885 \\
\hline
\end{tabular}




\subsection{Error Correction Model (ECM)}

As shown in table 4, ECM results indicate that foreign remittances have a negative significant short run impact on economic growth due to the consumption habits, but in the long run foreign remittances have significant impact because households start savings and switch from daily consumption towards investment, suggesting that it takes time before the impact is manifested. External debt has no significant impact on Indian economic growth in the short term, and this result is in line with the study of Krugman (1988) \& Hameed et al.(2008) but opposes to the findings of Aurangzeb \& Ul Haq (2012). However, FDI and ODA positively affect the short run economic growth, and ODA and FDI enhance the process of economic growth in the short run but not in the long run.

Table 4. ECM Coefficient Vectors

\begin{tabular}{|c|c|c|c|c|c|}
\hline & D(LNGDP) & D(LNREM) & D(LNEXD) & D(LNODA) & D(LNFDI) \\
\hline \multirow[t]{2}{*}{$\overline{\mathrm{D}\left(\operatorname{LNGDP}_{(-1))}\right.}$} & 0.279689 & 1.155249 & -0.033310 & -0.437201 & 7.242337 \\
\hline & $(0.28385)$ & $(0.55189)$ & $(0.17122)$ & $(1.08146)$ & $(2.61228)$ \\
\hline \multirow[t]{2}{*}{$\mathrm{D} \operatorname{LNGDP}_{(-2))}$} & 0.629002 & 1.001030 & 0.292188 & -0.519465 & 5.380925 \\
\hline & $(0.26202)$ & $(0.50944)$ & $(0.15805)$ & $(0.99829)$ & $(2.41138)$ \\
\hline \multirow[t]{2}{*}{$\mathrm{D}_{\left(\operatorname{LNREM}_{(-1))}\right.}$} & -0.182040 & -0.704292 & -0.142733 & 0.299261 & -2.581479 \\
\hline & $(0.12910)$ & $(0.25100)$ & $(0.07787)$ & $(0.49185)$ & $(1.18807)$ \\
\hline \multirow[t]{2}{*}{$\mathrm{D}_{\left(\operatorname{LNREM}_{(-2))}\right.}$} & -0.051250 & -0.235180 & -0.143153 & 0.049075 & -0.948340 \\
\hline & $(0.09301)$ & $(0.18083)$ & $(0.05610)$ & $(0.35435)$ & $(0.85594)$ \\
\hline \multirow{2}{*}{$\overline{\mathrm{D}\left(\operatorname{LNEXD}_{(-1))}\right.}$} & 0.654199 & -0.221550 & 0.305319 & -1.276071 & 1.847334 \\
\hline & $(0.29966)$ & $(0.58263)$ & $(0.18075)$ & $(1.14170)$ & $(2.75778)$ \\
\hline \multirow{2}{*}{$\mathrm{D}(\operatorname{LNEXD}(-2))$} & -0.622481 & 0.04 & -0.100228 & 1.748066 & 2.391810 \\
\hline & $(0.2$ & $(0.4$ & 97) & $(0.9$ & 393) \\
\hline \multirow[t]{2}{*}{$\mathrm{D}(\operatorname{LNODA}(-1))$} & 0.08 & 0.03 & 0.0 & -0.60 & 1.304156 \\
\hline & $(0.05$ & $(0.1$ & 08) & $(0.2$ & $(0.48947)$ \\
\hline \multirow{2}{*}{$\mathrm{D} \operatorname{LNODA}_{(-2))}$} & 0.028148 & 0.142417 & 0.101202 & -0.538704 & 0.840581 \\
\hline & $(0.05459)$ & $(0.10613)$ & $(0.03293)$ & $(0.20797)$ & $(0.50235)$ \\
\hline \multirow[t]{2}{*}{$\overline{\mathrm{D}\left(\operatorname{LNFDI}_{(-1))}\right.}$} & 0.025422 & 0.082530 & -0.003279 & 0.055106 & 0.247406 \\
\hline & $(0.02132)$ & $(0.04145)$ & $(0.01286)$ & $(0.08122)$ & $\overline{(0.19619)}$ \\
\hline \multirow[t]{2}{*}{$\mathrm{D}_{\left(\operatorname{LNFDI}_{(-2))}\right.}$} & 0.012353 & 0.104872 & 0.004614 & 0.045840 & -0.030421 \\
\hline & $(0.01981)$ & $(0.03851)$ & $(0.01195)$ & $(0.07546)$ & $(0.18227)$ \\
\hline \multirow[t]{2}{*}{$\mathrm{ECT}_{\mathrm{t}-1}$} & -0.409709 & -0.883676 & 0.142405 & 0.988117 & -7.903556 \\
\hline & $(0.26356)$ & $(0.51243)$ & $(0.15898)$ & $(1.00415)$ & $(2.42554)$ \\
\hline \multirow[t]{2}{*}{$\mathrm{C}$} & 0.017075 & 0.020212 & 988 & -0.007710 & -0.814682 \\
\hline & $(0.04716)$ & $(0.09169)$ & $(0.02845)$ & $(0.17968)$ & $(0.43402)$ \\
\hline R-squared & 0.402044 & 0.464273 & 0.773280 & 0.531706 & 0.456451 \\
\hline$\overline{\text { Adj. R- }}$ & 0.103066 & 0.196409 & 0.659920 & 0.297559 & 0.184677 \\
\hline
\end{tabular}

\section{Conclusion and Recommendations}

The main purpose of this study is to analyze the short-term dynamic changes and long-term equilibrium of foreign capital with Indian economic growth by using Johansan co-integration analysis and error correction model. The final result shows that there is a long-run equilibrium between variables during the period 1978-2014. In the short run, foreign remittances have a negative impact on Indian economic growth, the main reason for this is that foreign remittances are generally used for domestic consumption and very little for investment. However, with the passage of time, the positive impact of foreign remittances on economic growth can gradually be seen for the multiplier effect and more remittances used for productive investment (Gupta et al. 2009). As we know, foreign remittances are the most stable foreign capital in India and to a large extent can offset the deficit in commodity trade, thus maintaining a moderate current account deficit. In addition, foreign remittances can loose the financial constraints faced by many small and micro enterprises and raise the standard of living of the migrant families by improving income, consumption and savings (Singh 2011).

The short-run impact of external debt on Indian economic growth is insignificant, but the long-run effect is significantly positive. This indicates that the accumulation of external debt have become a common feature of developing economies with limited domestic resources, and external debt can help to bring about rapid economic growth in India in the long run. There is a negative relationship between FDI/ODA and GDP, indicating that neither FDI nor ODA can stimulate economic growth. This result suggests that FDI or ODA has no corresponding transmission mechanism to domestic enterprises and can only produce limited economic growth effects. The result in general is in line with previous studies by Gorg \& Greenwood (2002) and Burnside et al. (1997, 2000), indicating that foreign capital is unlikely to make wonders in India unless infrastructure is 
completely improved, regulations are relaxed and still more industries are opened up(Chakraborty et al. 2006).

So it is very important for Indian government to pay attention to producing the conducive policy environment for remittances and FDI and much focus should be on the side of policies to minimize external debt and ODA. Our findings suggest that the common belief that foreign capital can promote economic growth in developing countries is still a debatable issue in India. We propose effective policies and measures be taken to relax regulations, open up more industries to foreign investors, further improve the infrastructure to effectively attract and utilize FDI and remittances, lead more remittances to productive investment and finally achieve the sustainable positive effect of foreign capital on economic growth.

\section{References:}

Ahmad, H. M. \& Ahmad, M. Q. (2004). Foreign Capital Inflows and Domestic Savings in Pakistan: Cointegration Techniques and Error Correction Modeling.The Pakistan Development Review.41(4 ),825836.

Bacha, E.L. (1990).A Three-Gap Model of Foreign Transfers and the GDP Growth Rate in Developing Countries. Journal of Development Economics. 32, 279-296.

Blomstrom, M., R.E. Lipsey \& M. Zejan (1996). What Explains Growth in Developing Countries? In: W. Baumol, R. Nelson \& E. Wolf (eds.), Convergence of Productivity: Cross-National Studies and Historical Evidence. Oxford University Press, 243-59.

Burnside, C. \& Dollar, D. (1997). Aid, Policies and Growth. American Economic Review.90(4), 847-868.

Bussiere, M. \& Fratzscher, M. (2008). Financial openness and growth: Short-run gain,long-run pain? Review of International Economics . 16(1), 69-95.

Burnside, C. \& D. Dollar (2000). Aid, Policies and Growth. The American Economic Review.,90(4): 847-868.

Calvo, Guillemro, Leiderman, Leonardo, Carmen \& M.Reinhart (1994) .The Capital Inflows Problem: Concept and Issues. Contemporary Economic Policy. 12,112-132.

Chami, R., C. Fullenkamp \& S. Jahjah (2003). Are Immigrant Remittances Flow a Source of Capital for Development? IMF Working Paper, 03/189, Washington DC.

Emeka Nkoro (2012). Foreign Capital Inflows and Economic Growth in Nigeria:An Empirical Approach. Academic Journal of Interdisciplinary Studies. 1( 2),54-71.

Faini, Ricardo (2002). Migration, Remittances and Growth, September 2002, [Online] Available: http://www.wider.unu.edu/conference/conference-2002-3/conference\%20papers/faini.pdf

Findlay, R. (1978). Relative Backwardness, Direct Foreign Investment and the Transfer of Technology: A Simple Dynamic Model. Quarterly Journal of Economics. 92(1), 1-16.

Gorg, H. \& D. Greenaway. (2002). Much A do About Nothing? Do Domestic Firms Really Benefit from Foreign Direct Investment? Research Paper.2001/37,Globalisation and Labour Markets Programme, at Leverhulme Centre for Research on Globalization and Economic Policy, Nottingham.

Gupta, K. L. \& Islam, M. A., (1983). Foreign Capital, Savings and Growth: An International Cross-Section Study. Reidel Publishing Company: Dordrecht

Gupta, Sanjeev, Catherine A. Pattillo \& Smita Wagh (2009). Impact of Remittances on Poverty and Financial Development in Sub-Saharan Africa. World Development. 37 (1), 104-15.

Hameed, A., Ashraf, H. \& Chaudhary, M. A. (2008).External Debt and its Impact on Economic and Business Growth in Pakistan.International Research Journal Of Finance and Economics. 1 (20), 132-140.

Hansen, H. \& F. Tarp (2001). Aid and growth regressions. Journal of Development Economics. 64,547-570.

Jie Zhang \& Yong Lin (2018). Can Foreign Remittances Accelerate Economic Growth? An Empirical Analysis for China . Journal of Economics and Sustainable Development .19(10) ,188-195.

Krugman, P.(1988). Financing vs. forgiving a debt overhang: Some analytical issues. NBER Working Paper. No. 2486 ,Cambridge, Massachusetts: National Bureau of Economic Research.

Lipsey, R. (2003). Foreign Direct Investment, Growth, and Competitiveness in Developing Countries. in P. Cornelius, ed., The Global Competitiveness Report, 2002-2003. New York, Oxford University Press, 295305.

Mosley, P.(1980). Aid, Savings and Growth Revisited. Bulletin of Oxford Institute of Economics and Statistics. 42(2), 79-95.

Najid Ahmad, Arslan Ahmad \& Muhammad Farhat Hayat ( 2013).Foreign Remittances and Economic Growth in Pakistan: An empirical investigation. Munich Personal RePEc Archive. MPRA Paper No. 49132, posted 19. August 2013 13:56 UTC, [Online] available on http://mpra.ub.uni-muenchen.de/49132/

Oyinlola, O.(1995). External Capital and Economic Development in Nigeria (1970-1991). The Nigerian Journal of Economic and Social Studies. 37(3),205-222.

Razin, A. \& Sadka, E.(2001).Country risk and capital flow reversals. Economic Letters. 72(11), 73-77.

Spatafora, N. (2005). Workers' Remittances. IMF Research Bulletin. 6(4), 1, 4-5.

Stahl, C. (1982). Labour Emigration and Economic Development. International Migration Review.16, 868 - 99. 
Syed Shahbaz Hussain,Pirzada Sami Ullah Sabri, Zahra Amjad and Asjad Ghani Tahir(2013). Economic Growth of Pakistan: Effects of Foreign Capital Inflows. Pakistan Vision . 17(2), 2-14.

Waheed, A. \& Aleem, A. (2008). Foreign Remittances and Economic Growth: Empirical Evidence From Pakistan. Journal of Social Science and Humanities, 47(1), 1-12.

Yong Lin (2016) . Research Report on Overseas Chinese and International Remittances. Beijing: Guangming Daily Publishing House, 284. 